This is a self-archived version of an original article. This version may differ from the original in pagination and typographic details.

Author(s): Kerttula, Tero

Title: Digitaalinen viestintä on monimuotoista

Year: 2015

Version: Published version

Copyright: (c) Kirjoittaja \& Suomen Kansantietouden Tutkijain Seura, 2015

Rights: In Copyright

Rights url: http://rightsstatements.org/page/lnc/1.0/?language=en

Please cite the original version:

Kerttula, T. (2015). Digitaalinen viestintä on monimuotoista. Elore, 22(1).

http://www.elore.fi/digitaalinen-viestinta-on-monimuotoista/ 


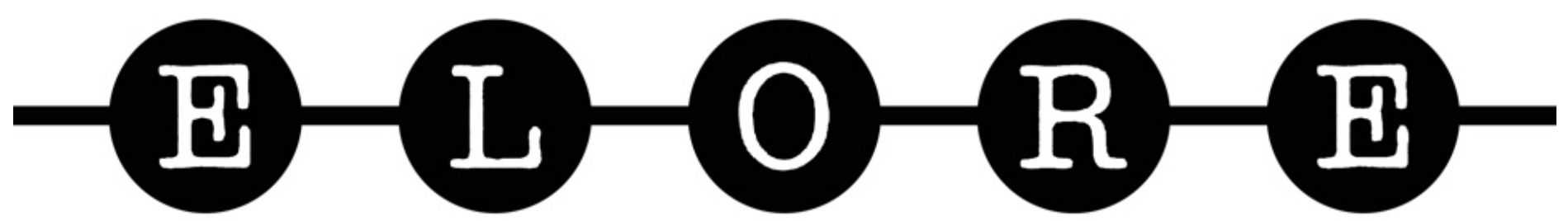

\title{
DIGITAALINEN VIESTINTÄ ON MONIMUOTOISTA
}

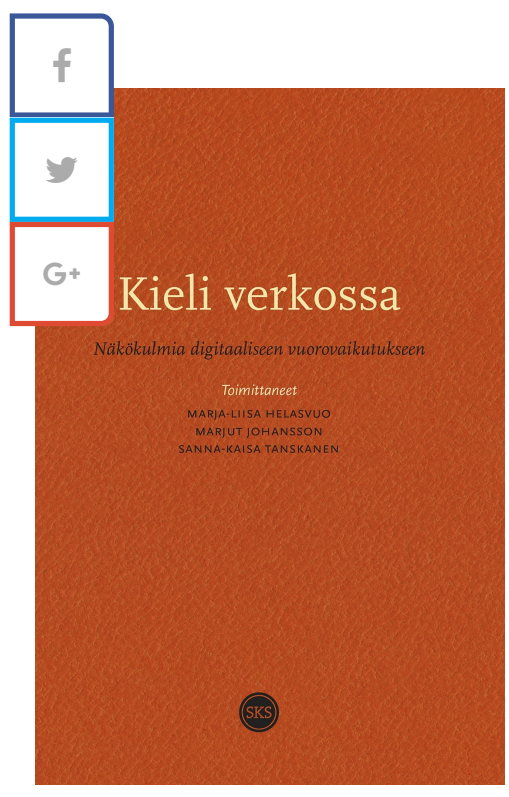

\author{
Helasvuo, Marja-Liisa, Johansson, Marjut \& Tanskanen, San \\ Kieli verkossa. Näkökulmia digitaaliseen vuorovaikutukseer \\ Kirjallisuuden Seura. 219 sivua.
}

\section{Tero Kerttula}

Ihmisten välinen viestintä on modernissa maailmassa painottunut yhä enemmän tapahtuvaan vuorovaikutukseen. Matkapuhelimet, blogit ja verkkokeskustelut ov päivittäistä viestintää. Tästä syystä digitaaliseen kieleen pureutuminen ja sen tut Helasvuon, Marjut Johanssonin ja Sanna-Kaisa Tanskasen toimittama artikkeliko digitaaliseen vuorovaikutukseen (2014) pyrkii tarkastelemaan näiden viestintämı puhe, myöskään digitaalinen vuorovaikutus ei ole arvovapaata tai tunteetonta.

Kirjan kuudessa artikkelissa lähestytään digitaalista vuorovaikutusta erityisesti kielentutkimuksen näkökulmasta näkökulmavivahteita myös muilta kulttuurin tutkimuksen kentiltä. Kirjan artikkelit käsittelevät aiheitaan pääsäär avulla. Artikkelit käsittelevät muun muassa tekstiviestikeskustelujen, keskustelupalstojen sekä eräänlaisten inte। radiolähetysten eli podcastien kieltä. Aihepiirien laajuuden ansiosta kokonaisuus esittelee digitaalisen viestinnär pelkästään esimerkkien ja niitä seuraavien analyysien kautta lukija saa hyvän kuvan erilaisten viestintämenetelm

Kirjan kohdeyleisönä ovat digitaalisen viestinnän opiskelijat, tutkijat sekä muuten aihepiirin parissa työskenteleı on hyvä, että kirjan johdantokappaleessa käydään digitaalisen kielentutkimuksen historiaa läpi ja sijoitetaan san tutkimuskentälle. Sisällöllisesti kirjan käsittelemiä tekstejä yhdistää ainoastaan niiden digitaalisuus. Sisällön puc liity toisiinsa, eikä peräkkäisten artikkelien välillä ole yhdistäviä tekijöitä. Jokaisen artikkelin näkökulmat poikke` tarjottavaa on periaatteessa monentasoiselle lukijakunnalle.

\section{Digitaalinen teksti}

Kirjan avaava osa on Marja-Liisa Helasvuon lingvistinen näkemys tekstiviestikeskusteluista osallistumisen ja kiel keskiössä oleva aineisto on laaja, 400 viestin mittainen, vaikka osallistujia tarkastellussa keskustelussa on vain I esimerkit ovat monipuolisia ja avaavat tekstin pääsanomaa hyvin. Koska aineisto on kerätty 2000-luvun alkuvuc ovat puhelintekstiviestit, vaikka kirjoittaja ei asiaa varsinaisesti täsmennäkään. Artikkelin tutkimusmenetelmät v 
hyödynnettävissä myös esimerkiksi Facebook- ja WhatsApp-keskustelujen analysointiin, sillä aineiston kieli on I verkkokeskusteluista. Kirjoittajan mukaan tekstiviestintää ei ole tutkittu kovin paljon. Artikkelillaan Helasvuo py tekstiviestit itsessään ole kategorioitavissa itsenäiseksi keskustelun genreksi. Artikkelissa havaitaan myös, että 1 johdu suoraan niiden lyhyydestä, vaan kenties ennemminkin viestin kirjoittamisen helppoudesta. Tämä selittäisi kohteena olevien subjektipronominimuotojen käytön.

Helasvuon artikkelia seuraava Sanna-Kaisa Tanskasen teksti verkkokeskustelujen osallistujuudesta alleviivaa an: myös muissa verkkokeskustelun konteksteissa hyvin, sillä Tanskasen käyttämät esimerkkitekstit eri keskustelup samankaltaisia. Tanskanen tarkastelee artikkelissaan metapragmaattisten kommenttien käyttämistä keskusteluk sitä, millaisia viittaussuhteita edellisiin kirjoittajiin keskustelijat luovat. Artikkelissa tarkasteltiin myös keskustelı kommentoinnin kautta. Aineistossa havaittiin kommenttien sisältävän tarpeeksi yhtäläisyyksiä aiemmin tutkittuj jotta analyysin perusteella keskustelupalstat voivat olla luokiteltavissa kielellisesti verkkoyhteisöiksi.

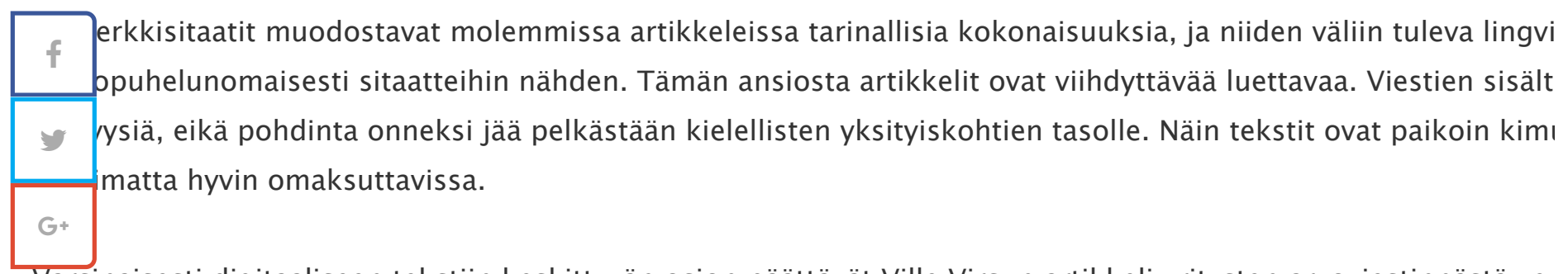

Varsinaisesti digitaaliseen tekstiin keskittyvän osion päättävät Ville Virsun artikkeli yritysten arvoviestinnästä veı poliittiseen blogiin pureutuva artikkeli. Erityisesti Virsun artikkeli poikkeaa kirjan kokonaisuudesta jopa huomat1 niin kieli- ja tekstilähtöinen kuin muut kirjan artikkelit, kenties johtuen tarkastelun kohteesta: verkkosivut viesti tavalla, ja niiden sisältö on vahvasti liitoksissa käytettävyyteen ja audiovisuaalisuuteen. Artikkeli ottaa tämän hur kokonaisuuden tasolla, mutta sopii kirjan muuhun teemaan silti hieman huonosti.

Kaisa Koskinen esittelee artikkelissaan blogi-ilmiötä laajemmin ja tuo esille myös blogeihin liittyvää tutkimusta. vain yhden poliittisen blogin analyysiin tunnetyön välineenä, vahva taustoitus puolustaa paikkaansa ja kertoo iln kiinnostuneille, jotka eivät tunne aihepiiriä. Koskisen mukaan blogi on genrenä vuorovaikutteinen, eli itse blogit liittyvät myös kommenttiosiot. Kommenttiosiot huomioidaan artikkelissa yhden lyhyen luvun verran, mutta niisti jäävät ymmärrettävästi analyysin ulkopuolelle.

\section{Digitaalinen puhe}

Kirjan keskivaiheilla oleva Fred Derwinin ja Tanja Riikosen itsen ja identiteetin rakentumista kulttuurienvälisissä artikkeli tarkastelee digitalisoitua puhetta kielen ja puhetavan näkökulmasta. Artikkelin esimerkkitekstit ovat sit podcasteista, joista toisessa henkilö käy monologia oman identiteettinsä rakentumisesta, kun taas toisessa käyc useamman henkilön kesken. Kielellinen itsen määrittäminen hallitsee analyysiä, mutta mukaan tulee silti näkökı mikä antaa analyysille myös etnologisen näkökulman.

Pelkistä teksteistä laajemmille urille lähtee myös kirjan päättävä Marjut Johanssonin artikkeli verkkolehtien medi referoinnista. Artikkelin esimerkit ovat videoesityksistä otettuja sitaatteja, mutta analyyseissä käsitellään toisina visuaalista puolta. Artikkelissakin mainittu Henry Jenkinsin käsite konvergenssista (Jenkins 2006, 3) tulee esimeı sidoksissa myös muihin viestintämekanismeihin - etenkin kun kyseessä ovat verkkolehdistä poimitut videoesityl lehtijournalismissa mahdollisia. Tämä tuodaan artikkelin aikana varsin hyvin esille ja kokonaisuudessa huomioic annettuun viestiin referoinnin lisäksi. 


\section{Yhteenveto}

Kokonaisuutena Kieli verkossa on hyvä kielitieteellinen katsaus verkkotekstien tutkimukseen. Kirja käsittelee kol monipuolisesti. Artikkelien kirjo tarjoaa esimerkiksi useita näkökulmia digitaaliseen keskusteluun useissa eri vii viestintävälineiden skaala on laaja, eikä kokonaisuudesta puutu sinänsä kuin kenties digitaaliset pelit - muista d kirja tarjoaa hyvää pohdiskeltavaa. Kirja tarjoaa lopun liitteissään katsauksen myös verkkoterminologian kehityk verkkosanaston. Kattava sanasto on riittävä kirjan artikkelien tarpeeseen ja toimii hyvin myös yleisenä verkkovie

Artikkelien terminologia on vahvasti kielitieteellistä, eikä se siksi välttämättä avaudu helposti kielitieteitä tunter kuitenkin oletetaan lukijan tuntevan tieteenalaa ja termistöä. Kuten takakansitekstissä todetaan, kirja soveltuu n keskustelusta kiinnostuneille. Henkilökohtaisesti olisin toivonut vielä paria painopistettä lisää - esimerkiksi digi1 verkkovideoiden kommentoinnin mukaan tuominen olisi tehnyt paketista vielä kattavamman. Kokonaisuus on kı

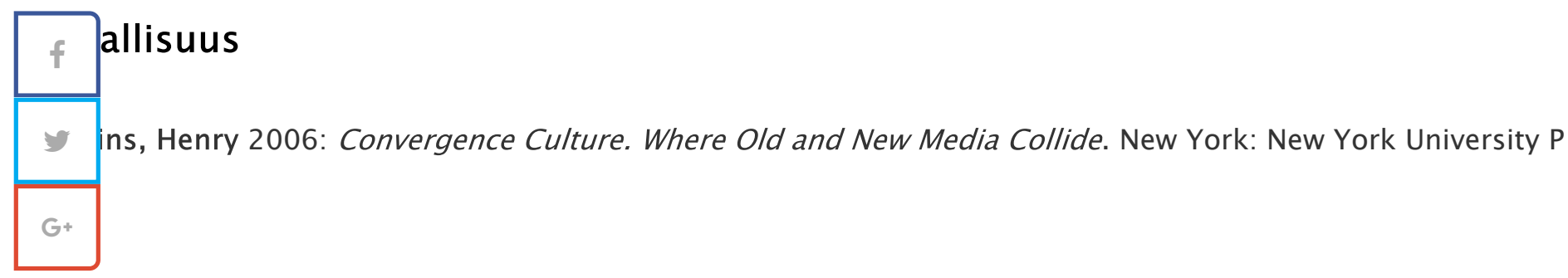

Filosofian maisteri Tero Kerttula toimii nykykulttuurin tohtorikoulutettavana Jyväskylän yliopistossa.
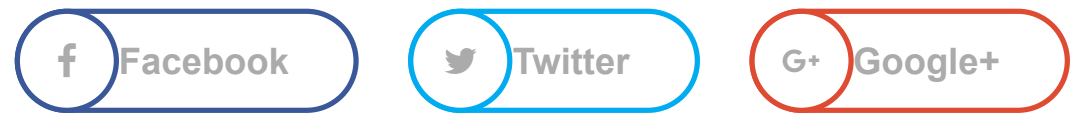

Posted in Elore 1/2015, Kirja-arviot on 5.6.2015.

Elore (ISSN 1456-3010) on tiettävästi

Suomen vanhin vapaan saatavuuden

verkkolehti. Elorea julkaisee Suomen

Kansantietouden Tutkijain Seura ry.

Logo: Jokke Saharinen

Taitto: Petja Kauppi, Tekstihuoltamo

Kielentarkastus (engl.): Tiina Mällo 
Eloren sivuston kopioiminen on kielletty

ilman päätoimittajan ja Kansantietouden

Tutkijain Seuran lupaa.

Viitattaessa julkaisun teksteihin lähteenä

mainitaan Elore ja viittaus tehdään

artikkelin URL-osoitteeseen.

Tätä julkaisua saa tulostaa ja valokopioida

muuhun kuin yksityiseen käyttöön

edellyttäen, että teoksen käytöstä

vastaavalla organisaatiolla on voimassa

valokopiointisopimus tekijänoikeusjärjestö

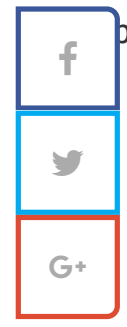

PROUDLY POWERED BY WORDPRESS · THEME: SUITS BY THEME WEAVER 